INTERDISCIPLINARIA ARCHAEOLOGICA NATURAL SCIENCES IN ARCHAEOLOGY

\title{
Tracing Archaeology through Geochemistry: an Example of a Disturbed Prehistoric Hilltop Settlement Site in South-Eastern Lithuania
}

\author{
Andra Simniškytè-Strimaitienè ${ }^{a^{*}}$, Aušra Selskienè ${ }^{b}$, Jūratė Vaičiūnienè $\dot{b}^{b}$ Vidas Pakštas ${ }^{b}$, Ramūnas \\ Šmigelskas ${ }^{a}$
}

${ }^{a}$ Lithuanian Institute of History, Kražiu g. 5, 01108 Vilnius, Lithuania

${ }^{b}$ Center for Physical Sciences and Technology, Saulètekio av. 3, 10257 Vilnius, Lithuania

\section{ARTICLE INFO}

\section{Article history:}

Received: $17^{\text {th }}$ September 2016

Accepted: $25^{\text {th }}$ April 2017

DOI: http://dx.doi.org/ 10.24916/iansa.2017.1.2

Key words:

subsurface features

archaeology

soil chemistry

$\mathrm{XRF}$ analysis

magnetic susceptibility

early $1^{\text {st }}$ millenium AD

\begin{abstract}
The aim of the research summarized in this paper was to describe soil properties from different contexts at an excavated hilltop settlement (subsurface features with artefacts, subsurface features holding no artefacts, and several sets of samples from substratum), to determine possible anthropogenic indicators at this locality, and to assess what, if any, are the differences of soil properties taken from the features with artefacts and those holding no artefacts. For this aim, 43 bulk soil samples were collected and analyzed for 16 chemical elements, magnetic susceptibility, soil organic matter and inorganic carbon, and $\mathrm{pH}$ values. The results revealed several sets of anthropogenic markers, among which the most distinguished were $\mathrm{P}, \mathrm{Mn}, \mathrm{Zn}$ and MS anomalies. A correlation between the presence/absence of artefacts and soil properties has not been detected. Anthropogenic sets were confirmed for almost all features with artefacts and for the major part of features holding no artefacts; thus the altered soil geochemical properties for these features can be assumed as an important additional cultural marker beyond that given by the archaeological remains. A handful of features with artefacts in one of them failed to be recognized as bearing any human-related signal; taking into account the circumstances, with reasonable care, they were categorized as disturbances having no archaeological value. No unambiguous interpretation is suggested for the analyzed subsurface features; rather they were considered in assessing various scenarios of archaeological context formation.
\end{abstract}

\section{Introduction}

The geoarchaeological research summarized in this paper followed the excavation of a heavily-disturbed Bèčionys hilltop settlement site in south-eastern Lithuania. The archaeological excavation revealed a distribution of subsurface features holding few or no artefacts. According to what was left of them - stains forms, profiles, fillings and artefacts (or absence of them) - all these were registered as sunken features, without any attempt of further interpretation of possible function (midden, posthole, hearth, etc.). The features with artefacts were doubtless worthy of documentation, at least regarding the archaeological value of their infill, whereas objects holding no artefacts lacked any such reason. The overall task, therefore, was to determine any culture-related criteria for these features.

*Corresponding author. E-mail: andrasimnas@gmail.com
Recent studies indicate that an analysis of geochemical and geophysical properties of sediments can contribute towards the detection of human occupation beyond the archaeological remains. This is because anthropogenic activity, including food preparation, fireplaces, middenning or craft-working, alters the natural sediments in recognizable ways, forming new soil characteristics that can be traced and measured through multi-analytical methodologies. To date, elevated levels of $\mathrm{Ca}, \mathrm{P}, \mathrm{Cu}, \mathrm{Fe}, \mathrm{Mg}, \mathrm{K}, \mathrm{Na}, \mathrm{Zn}$, etc., have been commonly found in archaeological soils and associated with specific inputs (Dirix et al. 2013; Entwistle et al. 2000; Hjulstrom, Isaksson 2009; Linderholm 2007; Linderholm, Lundberg 1994; Marwick 2005; Middleton, Price 1996; Middleton 2004; Parnell et al. 2002; Wells 2004; Wilson et al. 2008). However, the establishment of relationships between soil properties and past human activities is by no means straightforward. Ancient soil signatures are site- 
specific and often difficult to interpret due to the combined effect of natural variations in background geology, soilforming processes, complexity of site-use history, and methodological factors (Haslam, Tibbett 2004; Oonk et al. 2009a; 2009b; Wilson et al. 2009; López Varela, Dore 2010). It may be the reason for geochemical methodology being neglected in archaeological research projects, especially at disturbed sites.

The main idea of this paper is to describe the soil properties from different contexts at an excavated hilltop settlement (infill of subsurface features with artefacts, infill of subsurface features without artefacts, and several sets of samples from the substratum) using several geochemical and geophysical techniques. It was assumed that a comparison of these deposits must show what are the possible anthropogenic indicators at this locality, and whether there are any differences in the properties of soils taken from features with artefacts and those without. Under the circumstances of rescue archaeology, given the time shortages and economic circumstances, artefacts are often the only criterion to determine/deny the archaeological value of an object. This study, therefore, aims to assess if the presence/absence of artefacts is sufficient reason to justify this. It was also assumed that the spatial and functional links of consistent patterns of possible anthropogenic indicators might indicate the contemporariness of (back-) filling processes and/or related inputs. In Lithuania, only a few studies regarding the topic of ancient soil geochemistry for prospecting aims without subsequent excavations to test the collected data have been carried out so far, (e.g. Stančikaité et al. 2009; Bliujienè et al. 2012), therefore it was important to assess the advantages and limitations of this technique for excavated sites.

\section{Study area and archaeological site}

\subsection{Natural setting of the study area}

The study was undertaken in a remote rural area adjacent to the village of Bèčionys, Šalčininkai District, southeastern Lithuania (Figure 1). The area is characterized by a temperate climate with a mean annual temperature of $6.8^{\circ} \mathrm{C}$ and an average annual precipitation around $700 \mathrm{~mm}$.

The site surveyed is located in the western part of the Ashmena Upland (Basalykas 1965; Guobyte 2002). The landscape of the region was formed during the melting of lobes of the penultimate (Medininkai) glaciation (Figure 1). The end moraine formations and carbonated gravel-sandy glaciofluvial ridges have been mapped in the area. The last (Late Nemunas) glacier did not reach this region, but for a long period permafrost conditions prevailed here and the surface was intensively exposed to mechanical decay and

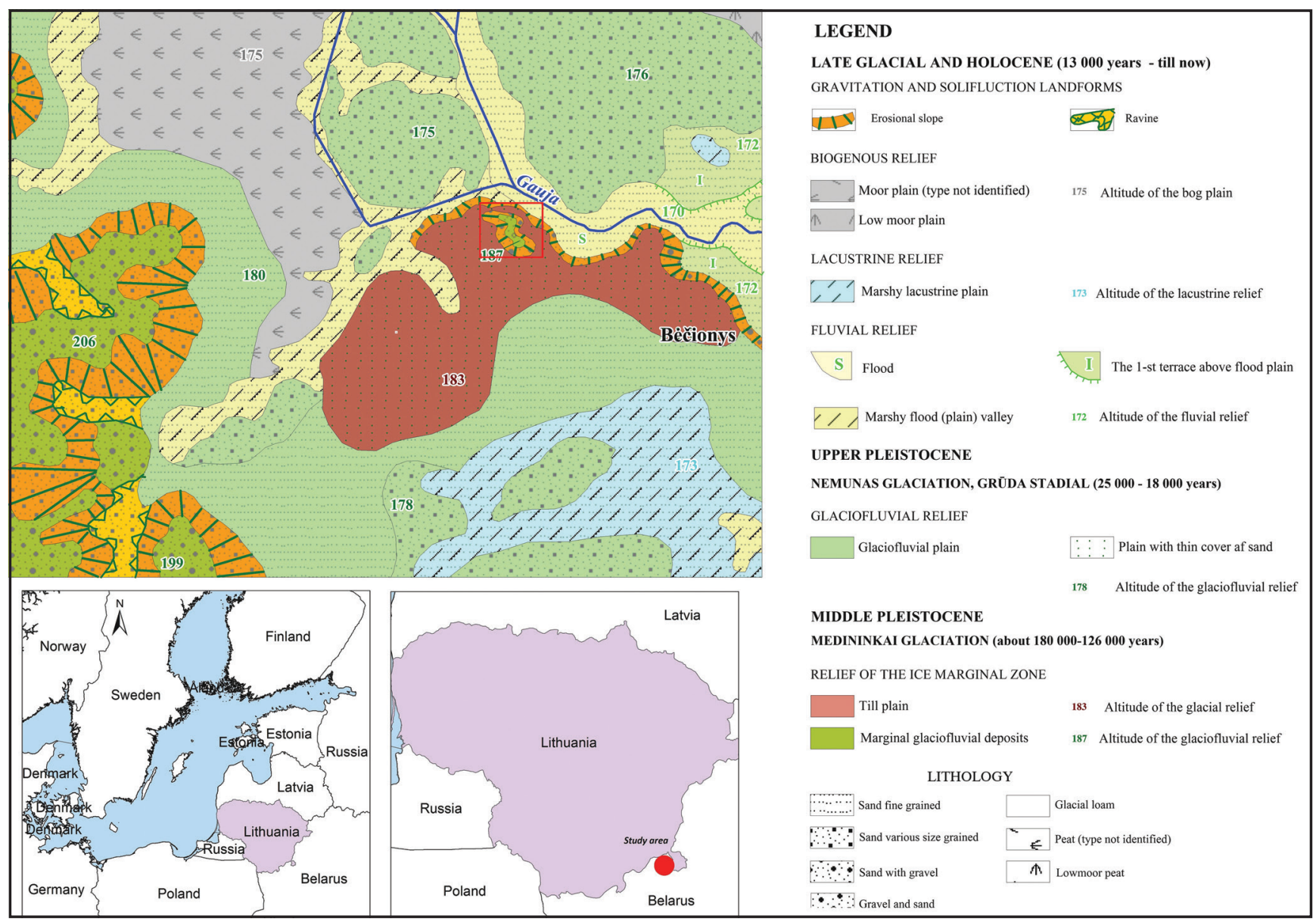

Figure 1. Quaternary geological-geomorphological map of the Běčionys area (originally compiled by J. Pocienė, Lithuanian Geological Survey). 


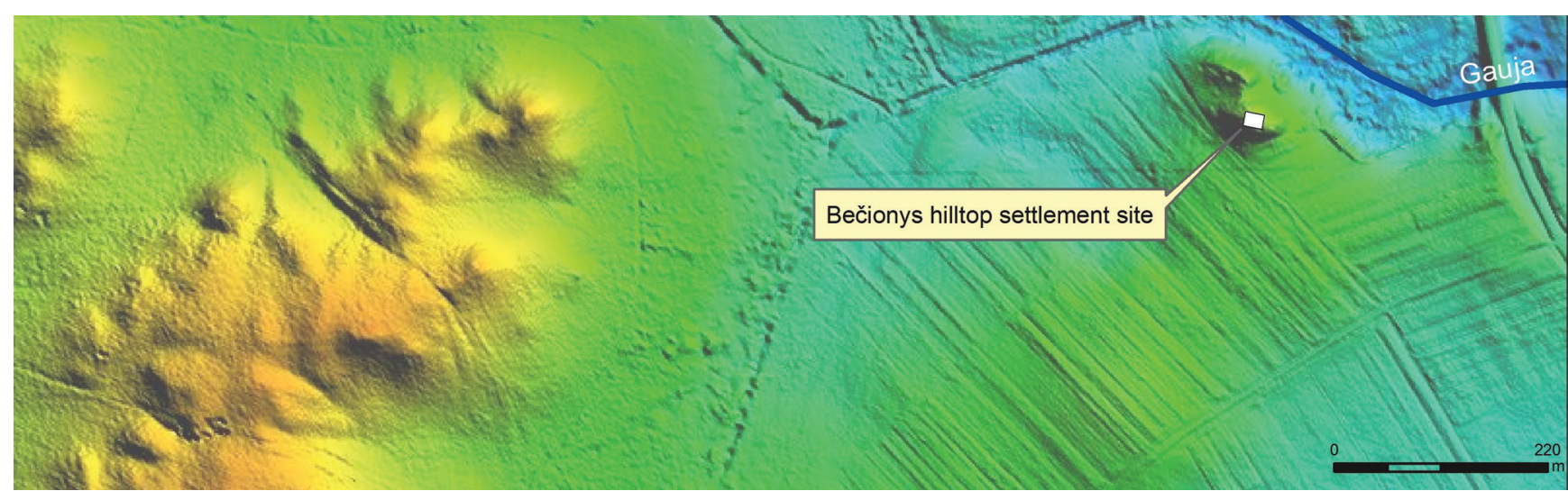

Figure 2. Situation of the Bèčionys hilltop settlement site and the uncovered area.

surface erosion processes. Hills have been deformed with periglacial ravines and the moraine-dominated landscape features eroded. One of the results of such erosion has been exposed in the central part of the area; it is a hill of a marginal glaciofluvial formation that once formed a part of a larger massive. Local soils are characterized by eutric calcaric arenosols with alkaline carbonate-rich coarse sand and gravel.

The archaeological site on the hill (WGS: N54 $13^{\prime} 12.5^{\prime \prime}$; E25 $\left.35^{\prime} 57.5^{\prime \prime}\right)$ is situated at an altitude of $185-187 \mathrm{~m}$, rising some 4-8 $\mathrm{m}$ on the right bank of the Gauja River (Figure 2). The top of the hill is oblong, orientated E-W, and $40 \times 20 \mathrm{~m}$ in size. To the north of the site lies the prolongation of a promontory, but it is not considered to be part of the archaeological site. The hill is covered by grassland, and the plateau and the slopes host about a dozen "potato cellars" or pits for gravel extraction.

\subsection{Cultural background}

The site was first recorded in 1951 and was regarded as a hilltop settlement of the so-called Brushed Pottery Culture, which thrived from the late $2^{\text {nd }}$ millennium $\mathrm{BC}$ to the early $1^{\text {st }}$ millennium AD. The positions of settlements on a hilltop represent the dominant type of habitation site in the East Baltic region in the first millennium BC (Grigalavičiene 1995; Vasks 1999; Medvedev 2011). Based on the prevailing mass of material discovered during the excavations of such sites over a hundred years (potsherds with brushed surface, tools of stone, bone and antler, animal bones), a common tendency persists to label all these hilltops settlements as early hillforts, assuming that all of them were more or less fortified long-term settlements for extensive families with a self-orientated subsistence strategy. The economy was mixed, stock-keeping and swidden agriculture playing major roles, hunting and fishing being subsidiary activities.

Figure 3. The hand-made pottery with brushed surface.

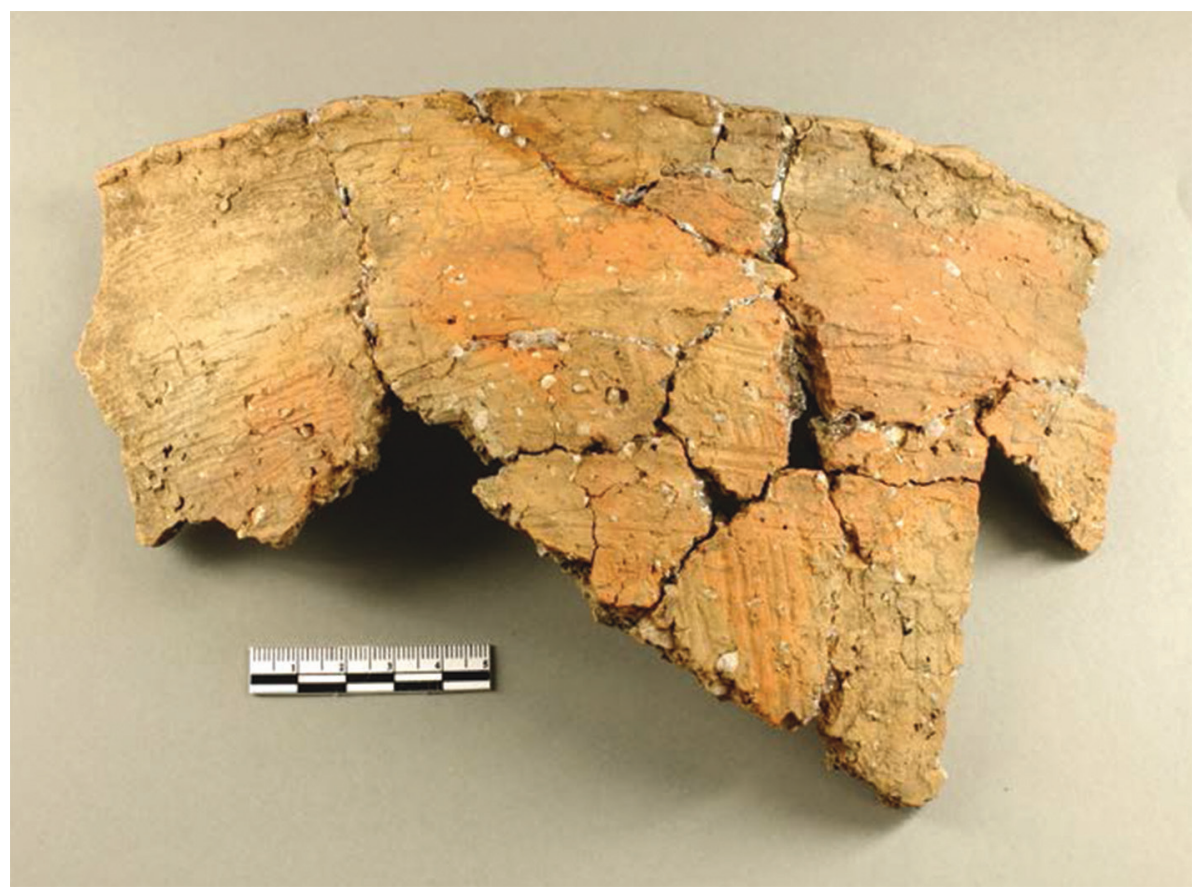




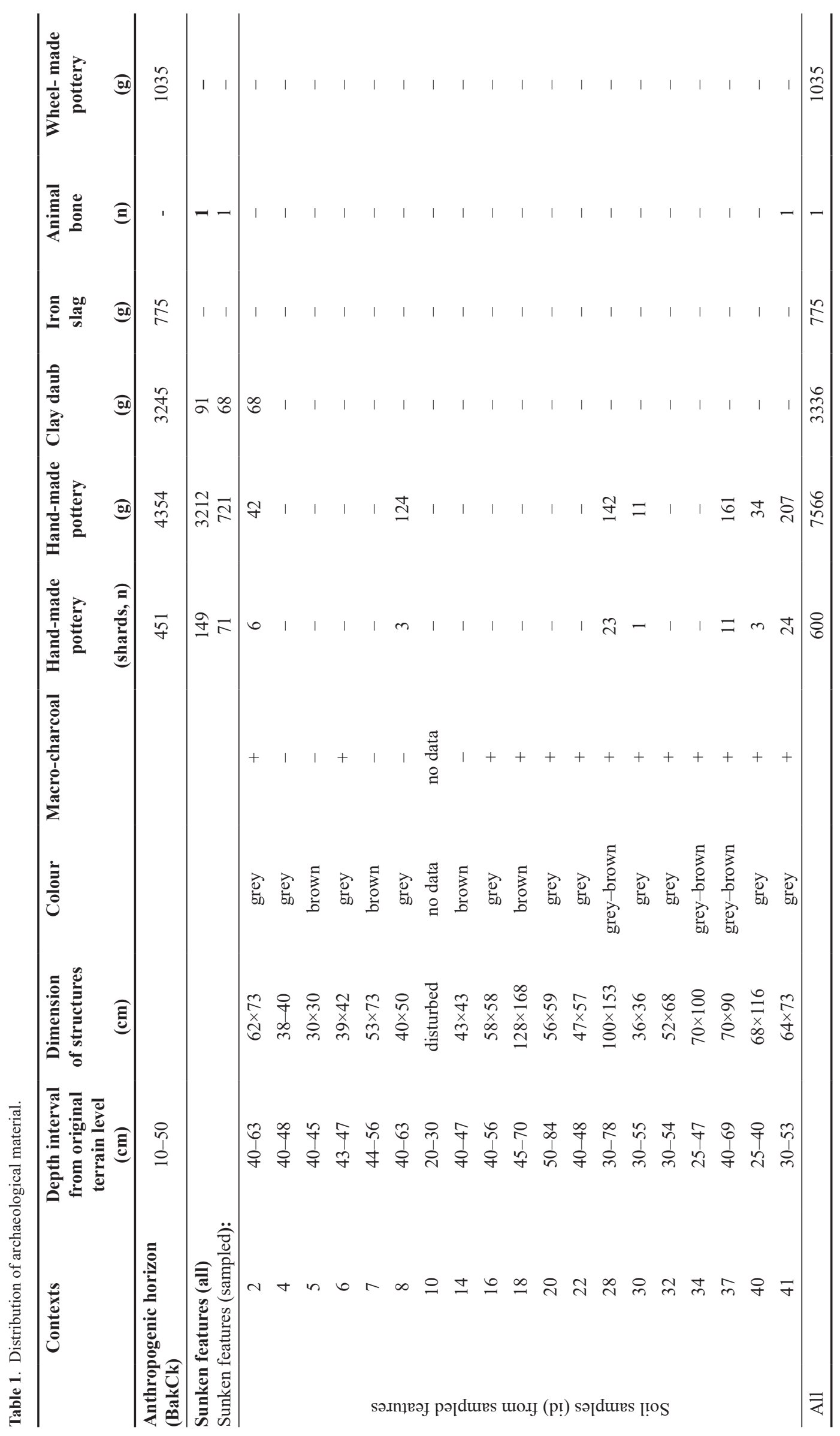



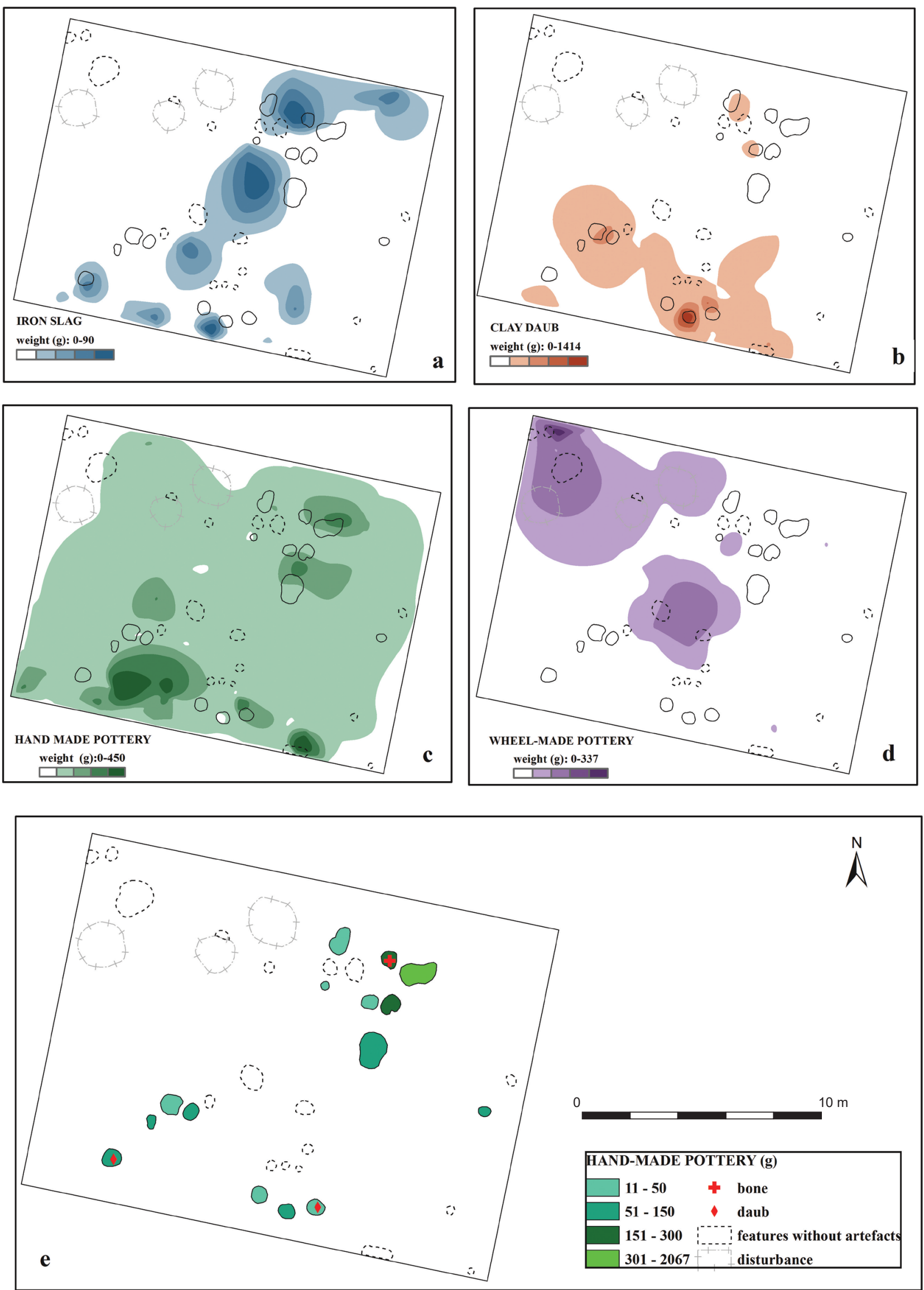

Figure 4. The distribution of archaeological material: in the anthropogenic layer BakCk (a-d) and features (e). 


\section{Material and methods}

\subsection{Field research, material and dating}

The excavation was performed by the public institution Academy of Cultural Heritage in 2012 (Šmigelskas 2013). A total area of $300 \mathrm{~m}^{2}$ was uncovered on the hilltop. As a result, almost the entire "hillfort" plateau was excavated. It appears that the cultural horizon had been destroyed in some zones of the area down to the substratum level (Ck). Only an anthropogenic brown gravel-sandy layer (BakCk) up to 10-20 $\mathrm{cm}$ thick was preserved at some spots between the horizons $\mathrm{A}(\mathrm{O})$ and $\mathrm{Ck}$. The thickest (up to $40 \mathrm{~cm}$ ) debris layer was in the $S$ part of the uncovered area, and a redistribution of material cannot be excluded given the sloping top of the hill with differences in altitude of 80-90 cm.

The anthropogenic layer contained most of artefacts (Table 1), predominantly hand-made pottery with brushed surfaces (Figure 3). Alongside the shards were found some clay wattle daub and an insignificant quantity of iron slag. Only one animal bone was discovered and enabled a radiocarbon AMS dating to $1960 \pm 30 \mathrm{BP}$ (Beta 349390). This date, along with the typological research, implies that the site was mainly used at the beginning of the $1^{\text {st }}$ millennium AD. Later, some kind of activities took place on the hilltop in the $15^{\text {th }}-16^{\text {th }}$ century, because several dozens of wheel-made pottery shards were also found. The spatial distribution of the collected material demonstrated no clear patterning; prehistoric artefacts and those of later times were clustered in different parts of the investigated zone with the pottery of historic times detected in the north-western part from a depth of $20 \mathrm{~cm}$ up to almost the surface (Figure $4 \mathrm{a}-\mathrm{d}$ ).

On the substratum level, at a depth of approximately 25-40 cm from the original terrain level, 34 pit-shaped features were found (Figures $4 \mathrm{e}, 5$ ). These features represent circular, oval or irregular outlines ranging from $22 \times 22 \mathrm{~cm}$ to $130 \times 170 \mathrm{~cm}$ in diameter. The upper parts of these features have obviously been swept away; only their lower parts, up to $30 \mathrm{~cm}$ in thickness, have survived. The half-sections of these features differ little in colour and texture from the surrounding geological substratum (Figure 6). The soil fill of these pits was greyish-brown and dark yellowish-brown sand, and some of them contained bits of charcoal. Although the features were adjacent to each other and form several groups, they had no explicit layout which could be attributed to specific building structures or any other architectural construction.

More than half of these pits contained no artefacts; others showed very poor artefact content, featuring mainly shards of hand-made pottery with an average weight of approximately $100 \mathrm{~g}$. Only one of these pits contained shards weighing over $2000 \mathrm{~g}$ in total, most of them being from the same vessel (Figure 3).

\subsection{Collection and preparation of the samples}

Of the 34, 19 pit-shaped features were bulk-sampled (Figure 7). These features were half-sectioned and samples were taken from the central part of the pit (19 samples) over the entire range of pit depths indicated in Table 1. Another 24 control samples were taken from the substratum level in order to determine the natural geochemical on-site background. Samples were taken from the substrate soil beside and underneath the pits (this strategy of samples acquisition, which resulted from an initial idea to assess phosphorus leaching from the pits, is not discussed here). All samples were grouped into four groups according to the sampling context:

Group 1 - features with artefacts (7 samples).

Group 2 - features holding no artefacts (12 samples).

Group 3-substratum samples taken at 25-40 cm depth interval (at the level of recorded "ouths" of the features) (8 samples).

Group 4 - substratum samples taken at $40-80 \mathrm{~cm}$ depth interval underneath the features (16 samples).

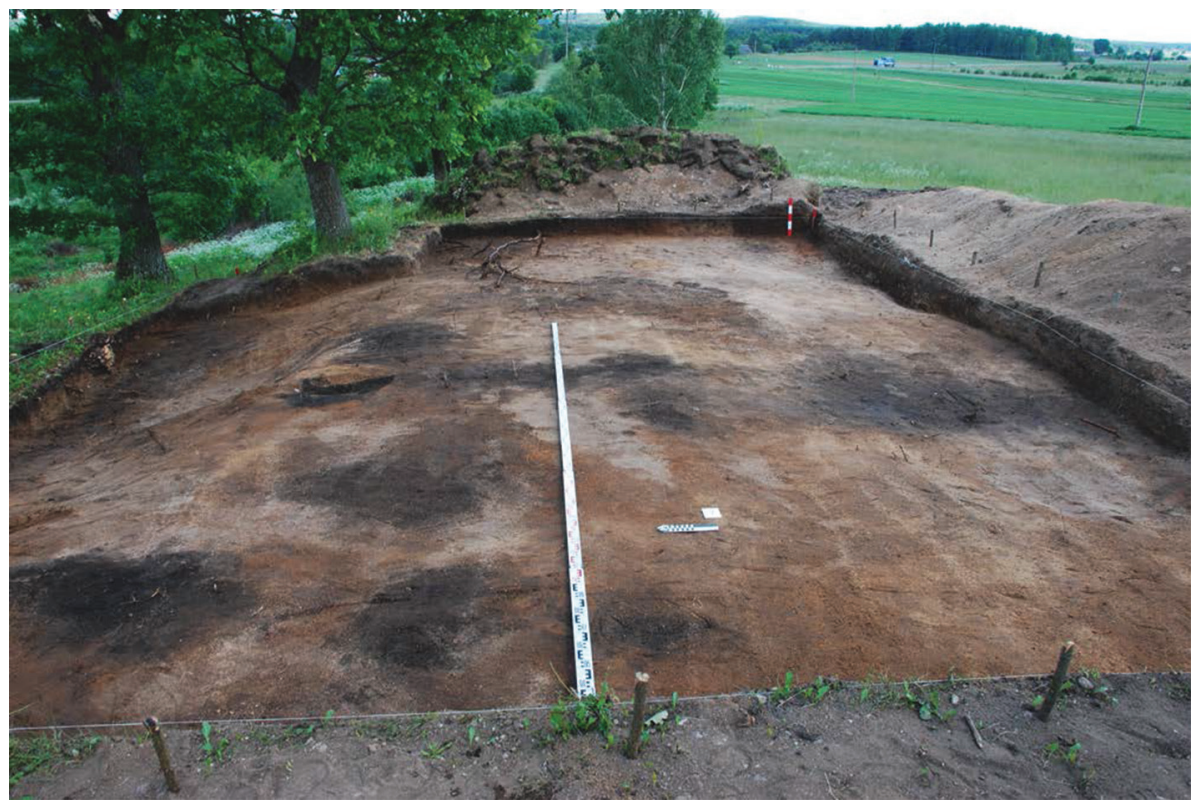

Figure 5. Pit-shaped structures in the northeastern part of the uncovered area. 

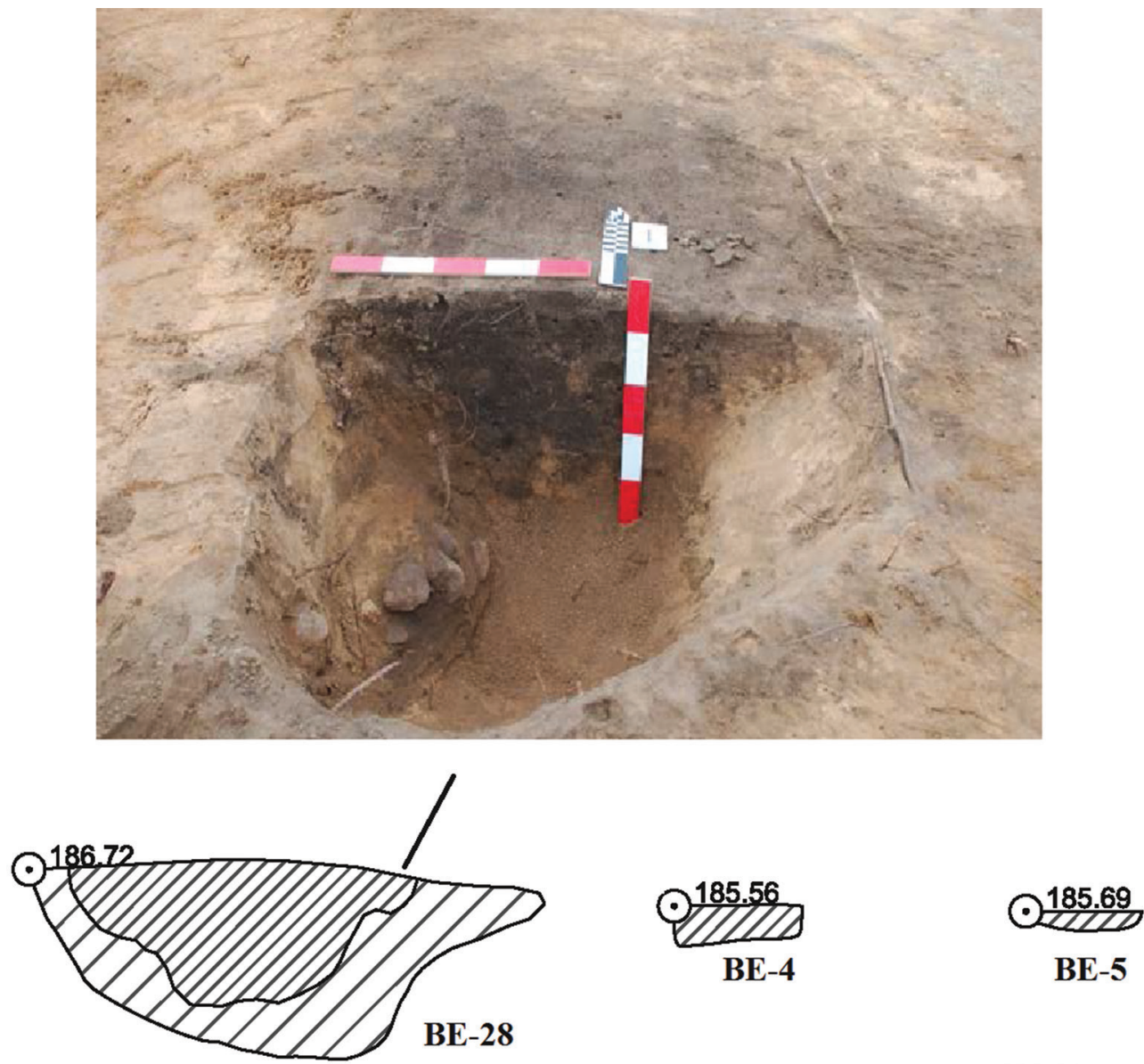

BE-4

BE-5

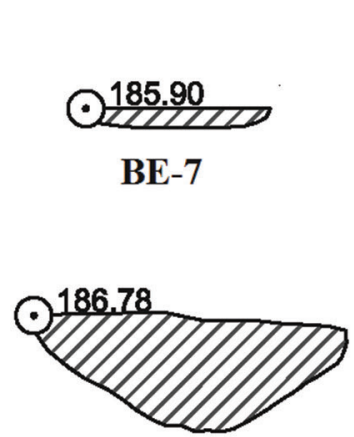

BE-32

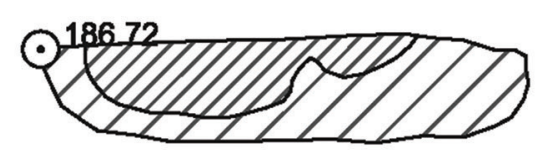

BE-34

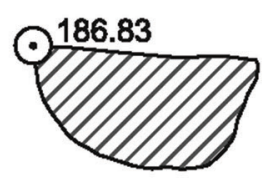

BE-30
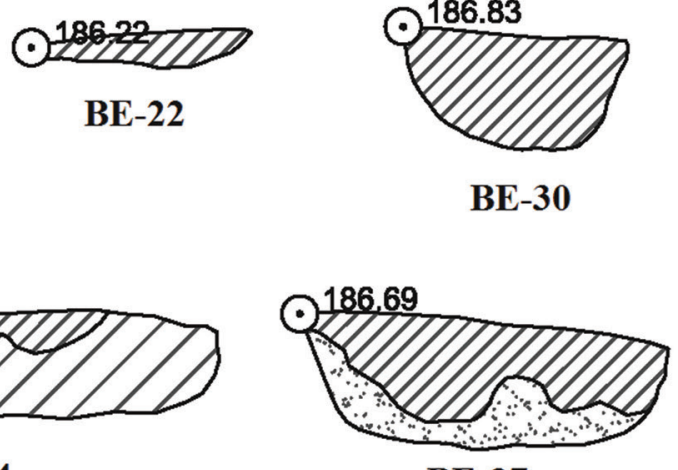

BE-37

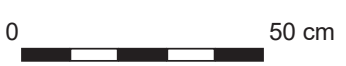

Figure 6. Examples of cross-sections of some of the pit-shaped features.

All 43 samples were air-dried and sieved using a $2 \mathrm{~mm}$ polypropylene sieve. Samples for XRF and LOI analyses were dried to a constant mass at $105^{\circ} \mathrm{C}$.

\subsection{X-ray fluorescence}

For multi-element analysis of soil samples, an X-ray spectrometer with a wavelength-dispersive detector Axios mAX (PANalytical, Netherlands, 2010) was used. Soil samples were prepared according to Buhrke et al. (1998) and Takahashi (2015): milled and $5 \mathrm{~g}$ of each sample was mixed with $1 \mathrm{~g}$ Hoechst wax $\mathrm{C}$ micropowder. The soil/binder mixtures were compressed into tablets using a hydraulic press applying a pressure of $150 \mathrm{kN} / \mathrm{cm}^{2}$ for $3 \mathrm{~min}$. The accuracy was determined using external standards N 139 (Czech Republic), NCS DC60105 (China), and IMZ-267 (Poland). In total 23 elements were measured, but some of them were eliminated due to having higher than $10 \%$ relative standard deviations in measurements of two tablets, or because their amount appeared to be lower than the detection limit. This paper presents the results from the major elements $(\mathrm{Si}, \mathrm{Al}$, $\mathrm{Fe}, \mathrm{Mg}, \mathrm{Ca}, \mathrm{Na}, \mathrm{K}, \mathrm{Mn}, \mathrm{P}, \mathrm{Ti})$ and trace elements $(\mathrm{Cu}, \mathrm{Rb}$, $\mathrm{S}, \mathrm{Sr}, \mathrm{Zn}, \mathrm{Zr})$. 


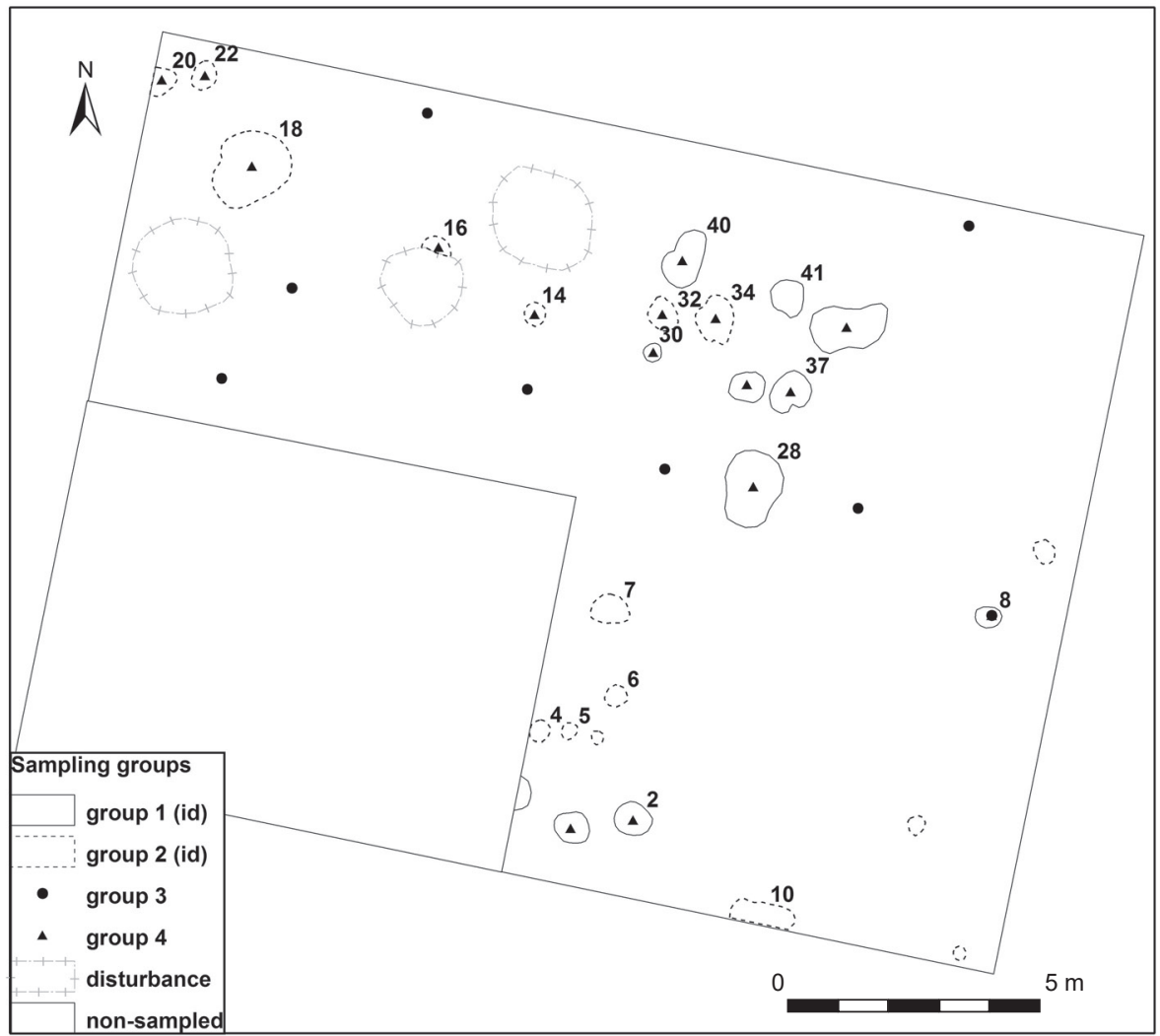

Figure 7. Sampling groups and sampling pattern (above); generalized profile of stratigraphic locations of the samples (below).

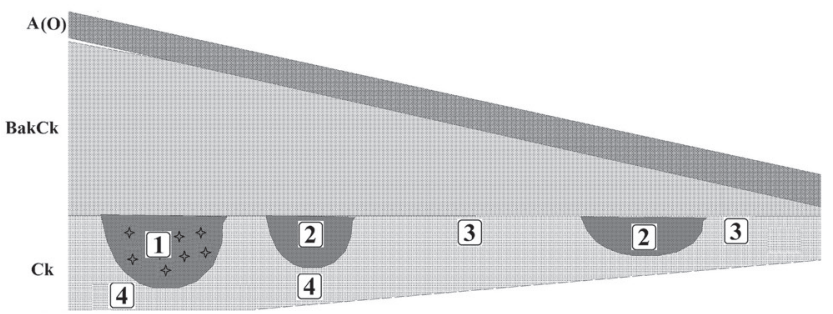

\subsection{Loss on ignition}

Loss on ignition (LOI) is a simple and broadly-used method for estimating the amount of soil organic matter (SOM) and soil inorganic carbon (SIC). SIC reflects the content of carbonate mineral in the soil. The investigated samples appeared to be slightly calcareous sandy sediments, so SOM and SIC were measured according to the method of Wang et al. 2013. Dried samples were combusted at fixed temperatures of $375^{\circ} \mathrm{C}$ for 17 hours and of $800^{\circ} \mathrm{C}$ for 12 hours. SOM was calculated as the weight loss between $105^{\circ} \mathrm{C}$ and $375^{\circ} \mathrm{C}$, and SIC as the weight loss between $375^{\circ} \mathrm{C}$ and $800^{\circ} \mathrm{C}$. In calculating SIC, the conversion constant of 0.273 was applied to convert the mass of $\mathrm{CO}_{2}$ to the mass of carbon.

\subsection{Soil pH}

Soil $\mathrm{pH}$ was measured as an indicator of soil preservation conditions. The measurements were conducted in a 1:5 sediment-to-deionized-water solution (shaken for 1 hour using a mechanical shaker, stored for 2 hours and filtered) with a $\mathrm{pH}$ meter Orion $3 \mathrm{Star}$ (Thermo Electron Corporation, USA) calibrated using buffer solutions of $\mathrm{pH} 4.01, \mathrm{pH} 7$ and pH 10.04 .

\subsection{Mass Magnetic Susceptibility}

Low frequency $(976 \mathrm{~Hz}$ with a field intensity of $200 \mathrm{~A} / \mathrm{m}$ ) magnetic susceptibility (MS) was measured for 5-50 g soil samples in a laboratory using a Multifunction Capabridge meter MFK1-B. The susceptibility values were normalized (using PC programme SAFYR6) by the mass of each sample and expressed as mass susceptibility. The results were recorded in mass specific units $\left(10^{-9} \mathrm{~m}^{3} \mathrm{~kg}^{-1}\right)$.

\subsection{Data analysis}

As a preliminary data exploration, some basic statistics were calculated for each variable and each sampling group. Element concentration values were normalized by z-score transformation prior to multivariate analysis. Further, 
the samples were regrouped on the basis of statisticallyinterrelated variables using hierarchical clustering based on Euclidean distance. To assess and compare distributions of variables, box-plots were calculated for each of the resultant clusters. Further, in order to analyze the data structure, a data reduction method was employed in which the element values were subjected to Principal Components Analysis (PCA). A bivariate plot of the first two component scores was overlain by a vector plot containing variable loadings. This representation combines the information on which variables differentiate between sample clusters with information on the relationship between individual variables. All statistical analyses were performed using Minitab 17, while spatial plotting was carried out with ArcMap 10.

\section{Results}

\subsection{In search of anthropogenic indicators: cluster analysis of variables}

To distinguish groups among the 20 variables which could be useful to archaeologists as possible anthropogenic indicators, a dendrogram was plotted and four main groups identified and classified into groups representing (Figure 8): 1) clay - Al, Fe, K, Na, Rb, Ti, (also including Sr); 2) carbonates $\mathrm{Ca}, \mathrm{Mg}$, SIC, pH; 3 ) silicaclastic group - Si, Zr; 4) biophilic elements P, Mn, Zn, magnetic susceptibility, accompanied by $\mathrm{Cu}, \mathrm{S}$ and $\mathrm{SOM}$. The latter group was presumed to be an anthropogenic indicator. To prove this assumption, the distribution of their values in different sampling contexts was analyzed in more detail.

\subsection{In search of anthropogenic indicators: cluster analysis of different sampling contexts}

A quick overview of some basic statistics for each initial sampling group is provided in Table 2. The low consistency of the results suggests the pattern of element variation varied substantially inside the sampling groups. To detect similar sets of samples and determine their characteristic pattern of properties, hierarchical clustering was performed using concentrations of 16 elements, SOM, SIC, $\mathrm{pH}$, and MS values. All samples were grouped according to the content of these variables and five clusters (CL.1-5) were selected based on the cluster dendrogram (Figure 9).

Statistical regrouping did not substantially change the samples distribution over the initial sampling contexts and separated, with only a few exceptions, the natural background samples from the subsurface features; however, the internal heterogeneity of these groups testified to the fact that similar soil properties are not necessarily shared by pits with artefacts and pits without. Figure 9 demonstrates three clusters (CL.2, CL.4, CL.5) on the right that include samples from sampling groups 1 and 2, which represent pit-shaped features with or without artefacts. On the left, one cluster (CL.3) comprises 11 samples from sampling groups 3 and 4 (3 and 8 samples, respectively), which represent the geogenic samples of the locality. CL.1 (18 samples) appeared to be the least homogeneous in terms of its sampled context and consists of 5 samples from sampling groups 1 and 2 ( 1 and 4 samples, respectively), and 13 samples from sampling groups 3 and 4 (5 and 8 samples, respectively). Judging from the connection distances of individual samples, soil properties for samples from different contexts in CL.1 often appeared to be more homogeneous in comparison to samples from CL.2, 4 or 5.

CL.1 does not show any marked variation in the concentration of variables as compared to those in other clusters. In CL.2, the quantities of most variables are moderately higher except for $\mathrm{Ca}(4.2 \mathrm{~g} / \mathrm{kg}), \mathrm{Mg}(1830 \mathrm{mg} / \mathrm{kg})$ and $\mathrm{Sr}(100 \mathrm{mg} / \mathrm{kg})$, whose concentrations in all the data collection were the lowest (Figure 10). CL.3 had the lowest concentrations for most of the variables except for $\mathrm{Ca}$. With a

Figure 8. Cluster analysis for all variables considered.

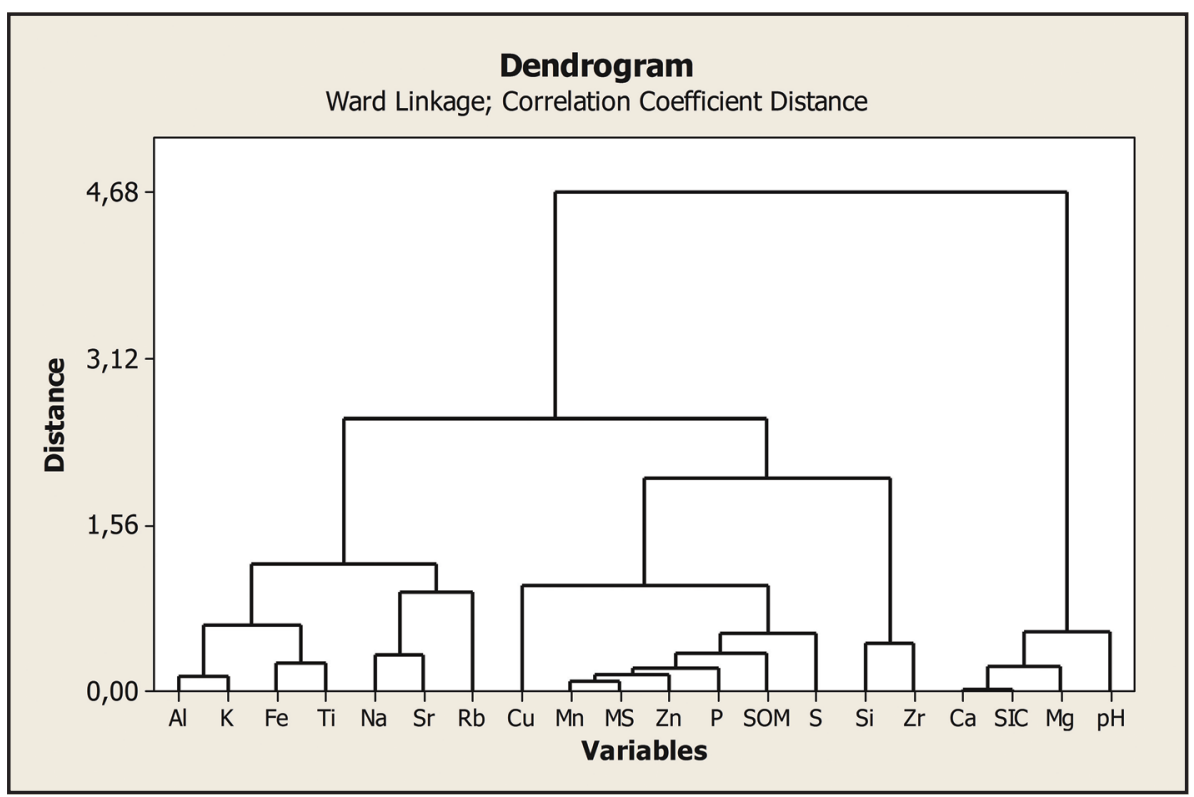




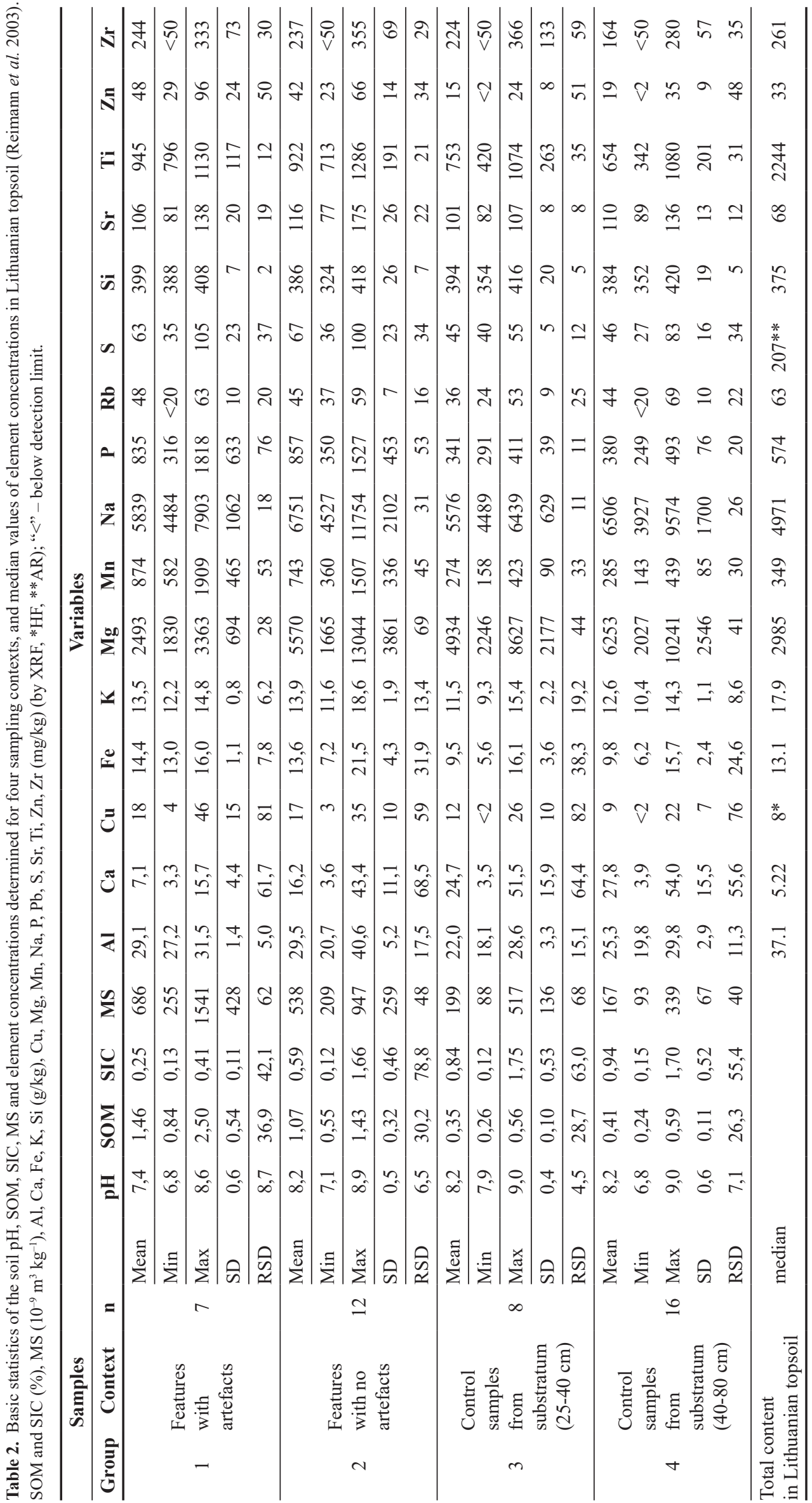


Figure 9. Resultant clusters of related samples.

median concentration of $39.4 \mathrm{~g} / \mathrm{kg}$, Ca values were six times higher than $\mathrm{Ca}_{\mathrm{LT}}$. CL.3 is also the most distinctive by virtue of its high $\mathrm{pH}(8.4)$ and SIC (1.4\%). In contrast, CL.4 had almost all its variables elevated with the highest concentrations for Al (34.6 g/kg), Fe (21.4 g/kg), K (15.9 g/kg), Mg (12.8 g/ $\mathrm{kg}), \mathrm{Na}(9131 \mathrm{mg} / \mathrm{kg}), \mathrm{Sr}(132 \mathrm{mg} / \mathrm{kg})$, approximating or
Ward Linkage; Euclidean Distance

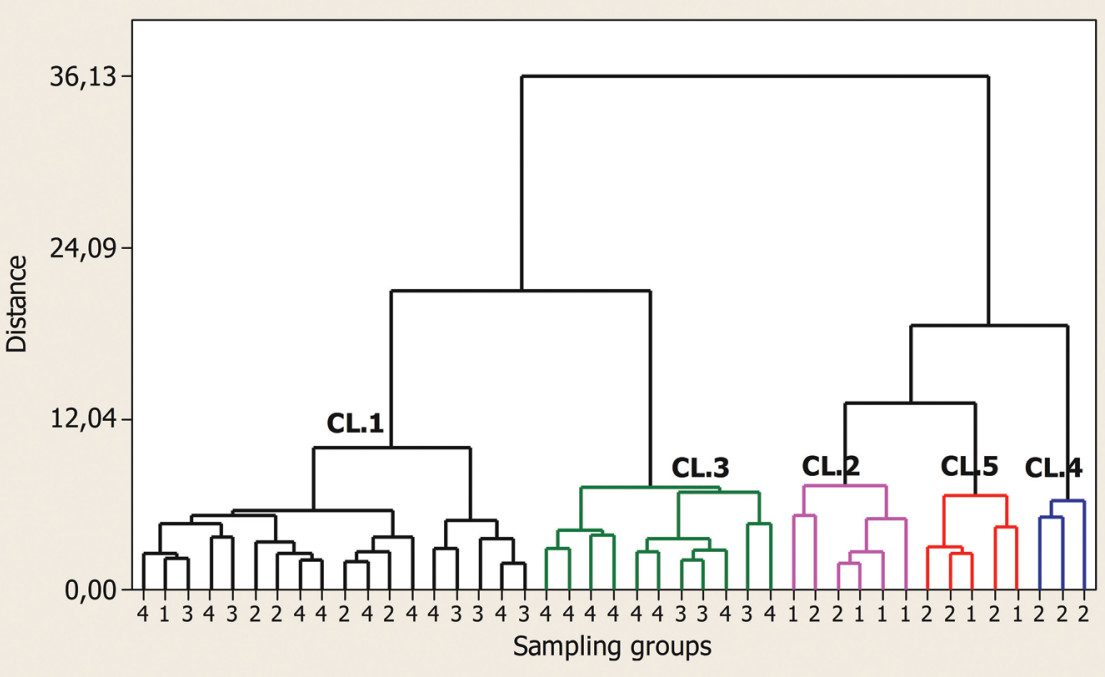

exceeding by two to three times the median concentrations of the Lithuanian topsoil layer. With a median concentration of $1527 \mathrm{mg} / \mathrm{kg}$ for P, $911 \mathrm{mg} / \mathrm{kg}$ for $\mathrm{Mn}$ and $64 \mathrm{mg} / \mathrm{kg}$ for $\mathrm{Zn}$, CL. 5 had the highest values of all the clusters - exceeding by two to three times the median concentrations from the Lithuanian topsoil layer (see Table 2). CL.5 is also highly

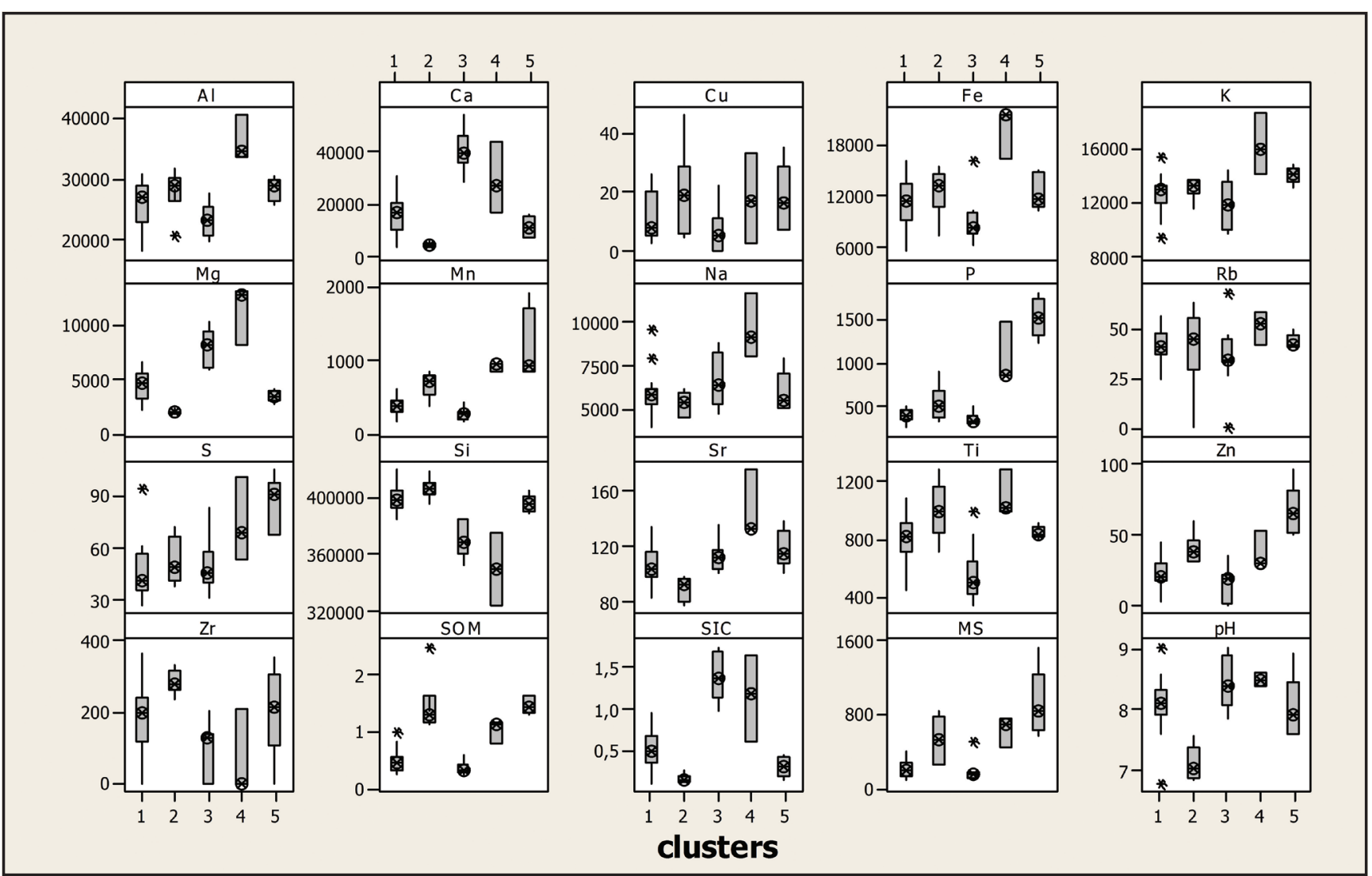

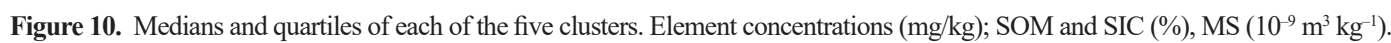


distinctive by having the highest MS values $\left(840 \times 10^{-9} \mathrm{~m}^{3}\right.$ $\left.\mathrm{kg}^{-1}\right)$.

\subsection{Compositional variation for pit-shaped structures: principal component analysis (PCA)}

A PCA was performed to analyse data structure variation for the samples of sunken features only (sampling groups 1 and 2). Eigen analysis of the correlation matrix indicated that the first four components with eigenvalues $>1$ accounted for $84 \%$ of the variability, and the first two accounted for $65 \%$ (Table 3 ). Any loading of more than \pm 0.40 was considered to be strongly loaded, $\pm 0.25-40$ moderately loaded and below \pm 0.25 weakly loaded in this study.

Table 3 shows that PC1, which accounts for $43 \%$ of the variance in the dataset, is moderately represented by $\mathrm{Al}$, $\mathrm{Ca}, \mathrm{Fe}, \mathrm{K}, \mathrm{Mg}$, Na, Si, Sr, SIC, Zr. PC2 (22\%) is strongly negatively represented by magnetic susceptibility and the biophile elements $\mathrm{Mn}, \mathrm{P}$ and $\mathrm{Zn}$, and moderately represented by $\mathrm{S}$ and SOM.

The distribution of the scores overlaid by plotted loadings (Figure 11) reveals that PC1 distinguishes CL.4 from CL.1, 2 and 5, with positive component scores for CL.4 and negative scores for 1, 2 and 5. PC2 differentiates CL.5 from CL.1 and 2 with high concentration of Mn, P, Zn and MS for CL.2 and reduced enrichment of these variables for CL.1 and CL. 2 with certain exceptions, that is a few CL.2 samples (eg. BE-41) appeared to be closer to CL.5.

Table 3. Loadings for pit-shaped structures. Loading values of $\pm 0.25-0.4$ are in bold, and above \pm 0.4 in underlined bold

\begin{tabular}{|c|c|c|c|c|}
\hline Variable & PC1 & PC2 & PC3 & PC4 \\
\hline $\mathrm{Al}$ & 0.288 & 0.032 & -0.283 & -0.099 \\
\hline $\mathrm{Ca}$ & 0.310 & 0.077 & 0.150 & 0.097 \\
\hline $\mathrm{Cu}$ & -0.021 & -0.054 & 0.244 & $-\underline{0.629}$ \\
\hline $\mathrm{Fe}$ & 0.286 & 0.056 & -0.154 & -0.230 \\
\hline $\mathrm{K}$ & 0.284 & -0.088 & -0.220 & -0.108 \\
\hline $\mathrm{Mg}$ & 0.323 & 0.051 & 0.043 & -0.036 \\
\hline $\mathrm{Mn}$ & 0.052 & $-\underline{0.443}$ & -0.011 & -0.114 \\
\hline $\mathrm{Na}$ & 0.312 & -0.003 & -0.095 & 0.083 \\
\hline $\mathrm{P}$ & 0.068 & $-\underline{0.415}$ & 0.069 & 0.127 \\
\hline $\mathrm{Rb}$ & 0.103 & -0.013 & -0.365 & $\underline{0.476}$ \\
\hline $\mathrm{S}$ & 0.070 & -0.323 & -0.015 & 0.143 \\
\hline $\mathrm{Si}$ & -0.336 & -0.022 & 0.033 & 0.028 \\
\hline $\mathrm{Sr}$ & 0.301 & -0.065 & 0.114 & 0.163 \\
\hline $\mathrm{Ti}$ & 0.078 & 0.131 & $-\underline{0.436}$ & -0.377 \\
\hline $\mathrm{Zn}$ & -0.026 & $-\underline{0.442}$ & 0.126 & -0.063 \\
\hline $\mathrm{Zr}$ & -0.270 & 0.070 & -0.184 & 0.117 \\
\hline SOM & -0.096 & -0.287 & $-\underline{0.405}$ & 0.021 \\
\hline SIC & 0.316 & 0.095 & 0.118 & -0.016 \\
\hline MS & 0.058 & $-\underline{0.432}$ & 0.016 & -0.098 \\
\hline $\mathrm{pH}$ & 0.196 & 0.058 & $\underline{0.429}$ & 0.196 \\
\hline
\end{tabular}

\section{Discussion}

\subsection{Possible anthropogenic indicators for the Bèčionys locality}

The primary task of this research was to identify the soil properties modified by human activity by distinguishing them from geogenic ones. It has been assumed that if values for an element do not deviate much across the site, then it most likely derives from the geological parent material, but if a variable has high deviations, then human inputs are more plausible explanation (Salisbury 2016). In Béčionys, one group of statistically-related $(\mathrm{p}<0.001)$ variables that had high RSD (relative standard deviation) and featured the consistent enhancement included $\mathrm{Ca}, \mathrm{Mg}, \mathrm{Sr}, \mathrm{SIC}$, and $\mathrm{pH}$. The elevation pattern of $\mathrm{Ca}, \mathrm{Mg}$ and $\mathrm{Sr}$ has been shown by numerous studies to correlate with the archaeological record and to be derived from bones, shells, and shell sand; these elements might indicate food preparation sites, wood ash and cultivated fields fertilized with domestic waste (Holliday 2004; Middleton, Price 1996; Middleton et al. 2010; Wilson 2008; Salisbury 2016), whereas high $\mathrm{pH}$ is related to ash and fireplaces (Entwistle et al. 1998; Holliday 2004; Dore, López Varela 2010). In Bèčionys, the concentration of SIC and alkaline earth metals was mostly high for samples from the substratum context (CL.3) and thus should be attributed to the calcareous geology of the site rather than to human activity. A positive correlation of $\mathrm{Ca}, \mathrm{Mg}$, SIC and $\mathrm{pH}$ indicates a large amount of $\mathrm{Ca}$ and $\mathrm{Mg}$ carbonates and their effect on a higher soil pH (Russo, Horrack 2000). For the pitshaped feature samples, the concentration of $\mathrm{Ca}$ and $\mathrm{Mg}$ was lower due to decalcification processes, although for some samples it was still high compared to median concentrations from the Lithuanian topsoil layer, most likely because of the presence of carbonated mineral additions.

As indicated in Table 2, phosphorus RSD in the pit infills was, on the average, four times higher than that in the substratum samples, which undoubtedly testifies to the anthropogenic origin of the variable (Entwistle et al. 2000). The relationship of $\mathrm{P}(\mathrm{p}<0.001)$ with $\mathrm{Mn}, \mathrm{Zn}$ and magnetic susceptibility, and the fact that the consistent enhancement of all of them was determined exclusively for those sediments taken from subsurface features, provides a basis to consider the entire group as dependable human-related indicators in this studied locality. This pattern was accompanied by an elevation in quantities of $\mathrm{Al}, \mathrm{Cu}, \mathrm{Fe}$ and $\mathrm{K}$. The increase in these elements sometimes significantly overshadowed the aforementioned "anthropogenic set" and, judging from the samples context, it represents another group related to human disturbance (CL.4).

Numerous studies have shown that the enhancement of $\mathrm{P}$, $\mathrm{Zn}$ and Mn can imply organic deposits, refuse, mineralized faeces, bones, etc. (Aston et al. 1998; Bintliff et al. 1990; Davidson et al. 2007; De Vos, Tarvainen 2006; Holliday, Gartner 2007; Linderholm, Lundberg 1994; Middleton et al. 2010; Oonk et al. 2009a; Ottaway, Matthews 1988; Parnell et al. 2002; Salisbury 2016; Wilson et al. 2008). The combustion process has been found to have a concentration 
Figure 11. Biplot of the scores and loadings for the first two PCA components for all variables in the sunken features (underlined - features with artefacts).

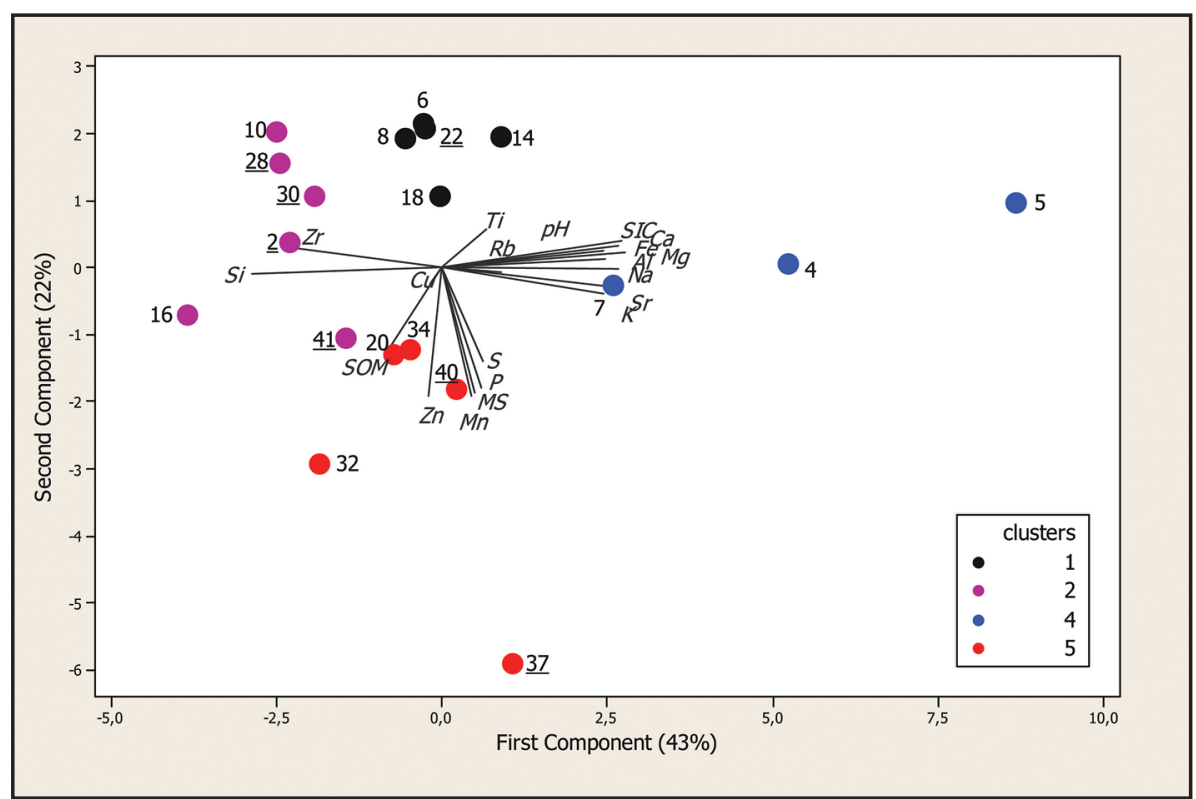

mechanism that suggests a role for bone and black carbonised particles in the post-depositional uptake and retention of enhanced elements (Aston et al. 1998; Middleton 2004; Davidson et al. 2007). As osteological material was barely found despite the preservation-favourable alkaline conditions in Béčionys, it can be assumed that the enrichment was caused mostly by plant-derived organics. In addition to $\mathrm{Ca}$, $\mathrm{Mg}, \mathrm{K}, \mathrm{Fe}$ and $\mathrm{Al}$, a significant amount of $\mathrm{P}, \mathrm{Mn}$, and $\mathrm{Zn}$ was found in the ash of biomass (trees and other plants), usually already in the form of a rather stable crystalline material (Gabet, Bookter 2011; Vassilev et al. 2013; Wang, Dibdiakova 2014). The anthropogenic input of $\mathrm{Ca}$ and $\mathrm{Mg}$ for Béčionys subsurface features might have been obscured by the geogenic concentration at this locality, but in general an enhanced $\mathrm{P}, \mathrm{Mn}$ and $\mathrm{Zn}$ (accompanied by a slight enrichment in $\mathrm{K}, \mathrm{Fe}$ and $\mathrm{Al}$ ) may imply a higher amount of ash and other burnt material (e.g. turf or dung) in the pit-shaped features. This assumption is supported by the macroscopic pieces of charcoal and elevated SOM. Higher amounts of Al, Fe, K, Ti and $\mathrm{Rb}$ may also testify to the presence of a clay admixture in the sandy layers. A few pits (BE-04, 05) during the field study were considered as possible postholes due to the absence of artefacts and their corresponding diameter. The distinguished anomalies of the aforementioned elements may suggest a cultural practice - the ends of wooden poles were often charred and/or plastered with clay.

Magnetic susceptibility is a physical property of soil linked mainly to the content of magnetic iron compounds. This property may change through the human disturbance of soils, water logging and microbial activity. An important quality of MS is its strong tendency to increase due to high temperatures, thus acting as an indicator of fires, even if the physical traces of fires are no longer detectable (Clark 1990; Dearing 1994). Thus, in Béčionys, the increase in MS might indicate the increased amount of combustion-affected soil, as well as particles of degraded pottery, clay daub, etc.

\subsection{The relationship of anthropogenic markers with the presence or absence of artefacts}

The "anthropogenic" pattern of significantly enhanced $\mathrm{P}, \mathrm{Mn}$, $\mathrm{Zn}$, MS was determined for six of the 19 sampled subsurface features (CL.5, including BE-41) and three of them contained no archaeological artefacts. CL.2 pits (three with artefacts and two holding no artefacts) were also similar in their interrelations of soil chemical elements and other properties, except that the concentration of anthropogenic markers here was much lower. The other set of possible human-related signals of $\mathrm{Al}, \mathrm{K}, \mathrm{Fe}, \mathrm{Mg}, \mathrm{Na}$ and $\mathrm{Sr}$ was determined for three features (CL. 4), all without archaeological evidence. The patterns of the remaining five sampled pit-shaped features from CL.1 showed no significant enrichment as compared to the background on-site values, except for a depletion of $\mathrm{Ca}, \mathrm{Mg}$ and SIC, which implies some disturbances of their natural properties. One of these five features contained some artefacts. All this demonstrates that there is no correlation between the presence/absence of artefacts and soil properties, and that the differences in soil properties between separate pit-shaped features holding artefacts, or between separate features without artefacts, might be greater than between these groups.

Human-related geochemical patterns were confirmed for 6 out of 7 of the features with artefacts, and for 8 out of 12 holding no artefacts, and therefore the altered soil geochemical properties for these 8 features can be assumed as important additional cultural markers beyond the archaeological remains. On the other hand, the remaining 5 features (with one of them holding artefacts) failed to be recognized as bearing any human signal. Morphologically these pits practically did not differ from the others. In the pits mentioned, the lowest amounts of organic matter, in comparison to the others (CL. $1-0.8 \%$, cf. CL. $4-1 \%$; CL. 2 and $5-1.5 \%$ each), may be considered the cause of them being overlooked by elemental analysis (Eberl et al. 2012). 
However, it is difficult to unambiguously evaluate the effect of OM quantity on the elemental composition as the OM differences were not great and OM did not correlate significantly with other variables: for example, various concentrations of $\mathrm{P}, \mathrm{Mn}$ and $\mathrm{Zn}$ were determined for identical OM amounts in CL.2 and CL.5. The pits without marked variations in soil properties may not have even been purposefully formed, and they are just post-depositional disturbances of no archaeological value (e.g. backfilled animal burrows, hollows for gravel extraction, etc.), where artefacts had found their way accidentally. Recognition of such pits should be considered as a peculiar advantage of the method: enabling one to determine archaeologically worthless features, which would otherwise prove difficult to separate applying conventional methods. However, if the presence of artefacts in one of them is not incidental, the version of different object type with specific pit infill should be considered, though the analysis procedure used in this work is inadequate for its development. This also flags up a warning that so-called conventional anthropogenic indicators might fail to provide a complete picture of the activity distribution and diversity not related to organic content. This fact should be taken into consideration when trying to establish boundaries or the intensity and diversity of anthropogenic activities on non-uncovered habitation sites.
Because if subsequent excavations only target areas with high levels of biophilic variables, the resulting evidence will allow the unveiling of an incomplete picture of activities.

\subsection{Spatial and functional links of anthropogenic markers in the archaeological context}

There are no unambiguous interpretations for many of the subsurface features. Usually, the function of the features is assumed on the basis of their shape, equipment, and artefacts, while bearing in mind that the same feature could have been used for different purposes or their use could have changed with time (Schiffer 1987). In Bèčionys, the appearance of the features and the artefacts discovered within them provided little clue as to the nature of the pits and their relation to human activity. Even after the anthropogenic indicators have been elucidated, it is difficult to determine not only what type of objects they represent, but even whether they reflect refuse management, natural backfilling, or result from post-deposition (bioturbation, disturbance, etc.) Perhaps it would be possible to characterize the nature of the objects in more detail if they were grouped together: by identifying spatial and functional links with their general archaeological context.

Pit-shaped features distinguished for their increased P, Mn and $\mathrm{Zn}$ quantities and magnetic susceptibility were spatially

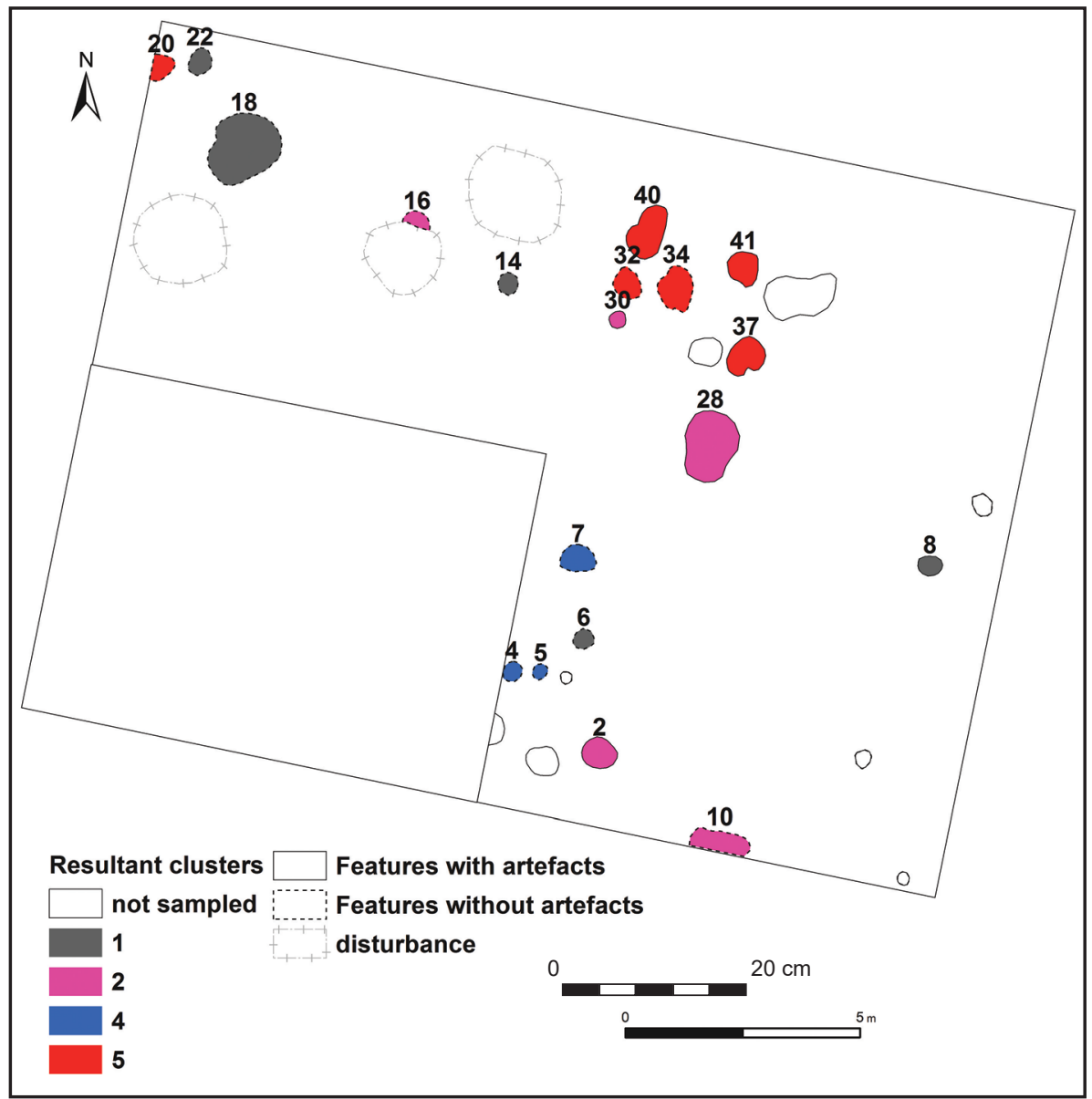

Figure 12. Spatial distribution of the resultant clusters in the sunken features (BE-41 was assigned to CL.5 cf. PCA data). 
concentrated (Figure 12, BE-32, 34, 37, 40, 41), which suggests that they might have been deposited from related inputs and/or they might have been filled in about the same time. The radiometric dating of the single bone found in one of these features (BE-41) indicated material from the first century AD. This feature and the adjacent ones contained shards dating approximately to the same period. One of them (unfortunately unsampled for geochemical analysis) contained shards (weighing $2 \mathrm{~kg}$ ) from one broken pot. It looked like the pot had ended up in the pit being at least partly unbroken, and as such big shards do not usually stay on the surface for long, it should have been deposited into the pit either directly from the living (systemic) context or soon after the site was abandoned.

One of the pits located at a distance (BE-20) with anomalies characteristic of CL.5 was documented as a later disturbance, which points one towards considering a completely different scenario - the pits might have been excavated much later, digging over an already homogenized cultural layer that had become the pit infill itself. Inasmuch as samples from the anthropogenic layer (BakCk) were not taken, there remained no possibility to examine them geochemically. Nevertheless, it is noteworthy that the density of the prehistoric artefacts (pottery, daub, slag) in the anthropogenic layer was rather high; it therefore remains unclear as to why such a great number of pits held no artefacts, while others contained only prehistoric pottery (about $43 \%$ of its total amount), merely $3 \%$ of daub and no fragments of slag. Although the amount of the latter found in the settlement was not great, the major part of it in the anthropogenic horizon was concentrated around the aforementioned pits (Figure 4a). If the pit sediments were parts of the slipped intermixed cultural layer, then - on the basis of anthropogenic sets distribution - it can be suggested that the homogenization of sediments did not occur over the whole site, but only in certain spatial segments, perhaps even preserving certain links with the primary purpose of these zones. This suggestion is supported by the concentration of features with enhanced $\mathrm{P}, \mathrm{Mn}, \mathrm{Zn}$ and MS (CL.5). That this pattern overlaps with the slag distribution is not necessarily accidental; however, without determining the chemical composition of the slag it would be too early to assign some or all of the anomalies (for example, of $\mathrm{Mn}$ ) directly to iron smelting activities. In general, $\mathrm{Zn}$, $\mathrm{Mn}, \mathrm{P}$, and MS enrichments, as well as bits of charcoal in the pit-shaped features, imply a higher amount of ash and other burnt material and can be considered as evidence of fuel for metallurgy. Several pits with high amounts of Al, Fe, $\mathrm{K}$ and $\mathrm{Na}$ were located southward. Two pits were assumed as former postholes, while a clay daub concentration found nearby (Figure $4 \mathrm{~b}$ ) is suggestive of a wooden construction that had potentially stood there. No continuity in the arrangement of the other pits was observed. However, worthy of note is that three CL.1 pits, whose geochemistry did not differ from that of the subsurface, were detected in the most disturbed NW part of the excavated area, which does not contradict the assumption that these features most likely have no archaeological value.

\section{Conclusion}

While it is indeed difficult to directly interpret chemical soil data in terms of ancient human activity, the results demonstrate that the multi-proxy approach does have the potential to complement the traditional archaeological techniques with an extra dimension.

Multivariate statistics revealed several sets of anthropogenic markers. On the basis of their spatial and functional links, $\mathrm{P}, \mathrm{Mn}, \mathrm{Zn}$ and MS anomalies were explained as the burning of fuel (for metallurgical activities?), while the unusual enhancement of $\mathrm{Al}, \mathrm{Fe}, \mathrm{K}, \mathrm{Na}$ and $\mathrm{Sr}$ was assumed to result from an infill that contained more clay (clay daub, clay-plastered poles). $\mathrm{Ca}, \mathrm{Mg}$, accompanied by high $\mathrm{pH}$ and SIC were considered as geogenic variables whose local enrichments could be explained by the calcareous geology.

There is no correlation between the presence/absence of artefacts and soil properties, and the differences of soil properties between separate pit-shaped features holding artefacts, or between separate features without artefacts, might be greater than that between these groups. Anthropogenic sets were proved for 6 features out of 7 with artefacts, and for 8 out of 12 features holding no artefacts; the altered soil geochemical properties of these 8 features can therefore be assumed as an important additional cultural marker beyond that given by the archaeological remains. On the other hand, 5 features - one of which included artefacts - failed to be recognized as bearing any human-related signal, most likely due to their low OM content. At least some of these pits are most probably post-depositional disturbances of no archaeological value and the recognition of such pits should be considered as a peculiar advantage of this method that enables one to determine archaeologically worthless features.

No unambiguous interpretation is suggested for the subsurface features; rather they have been discussed in assessing different scenarios of archaeological context formation. The archaeological data (types of artefacts, size effect) and soil geochemistry (sets of anthropogenic markers), as well as their spatial and functional links, suggest that the sediments must have been deposited into the pits either directly from the living (systemic) context or soon after the site was abandoned. Even if it had happened much later, and the pits sediments are parts of an intermixed cultural layer, then according to the distribution of the sets of anthropogenic markers, it may be supposed that homogenization of the anthropogenic sediments did not occur on a scale of the whole site, but rather covered only certain spatial segments - possibly preserving certain links with the primary purpose of these zones.

\section{Acknowledgements}

The research was conducted as part of the scientific project "Geoarchaeological soil research as a means to investigate ancient settlement sites" financed by the Lithuanian Scientific Board (MIP 101/2015). 


\section{References}

ASTON, M. A., MARTIN, M. H., JACKSON, A. W. 1998: The use of heavy metal soil analysis for archaeological surveying. Chemosphere 37, 465-477.

BASALYKAS, A. 1965: Lietuvos TSR fiziné geografija (2. Fiziniai geografiniai rajonai). Mintis, Vilnius.

BINTLIFF, J. L., DAVIES, B. E., GAFFNEY, C. F., WATERS, A. 1990 Trace metal accumulation in soils on and around ancient settlements in Greece. In: Bottema, S. Entjes-Nieborg, G., van Zeist, W. (Eds.): Man's Role in Shaping of the Eastern Mediterranean Landscape. Balkema, Rotterdam, 159-172.

BLIUJIENĖ, A., STANČIKAITĖ, M., KISIELIENĖ, D., MAŽEIKA, J., TARAŠKEVIČIUS, R., SZWARCZEWSKI, P., MESSAL, S., KUSSIAK, J., STAKĖNIENĖ, R. 2012: Skomantai Hill-Fort in Western Lithuania: A Case Study on Habitation Site and Environment. Archaeologica Baltica $17,101-135$.

BUHRKE, V. E., JENKINS, R., SMITH, D. K. 1998: A Practical Guide for the Preparation of Specimens for X-ray Fluorescence and X-ray Diffraction Analysis. Wiley-VCH, New York.

CLARK, A. 1990. Seeing Beneath the Soil: Prospecting Methods in Archaeology. Routledge, New York.

DAVIDSON, D. A., WILSON, C. A., MEHARG, A. A., DEACON, C., EDWARDS, K. J. 2007: The legacy of past manuring practices on soil contamination in remote rural areas. Environment International 33/1, 78-83.

DEARING, J. 1994: Environmental magnetic susceptibility: using the Bartington system. Bartington Instruments, London.

DE VOS, W., TARVAINEN, T. 2006: Geochemical Atlas of Europe. Part 2 - Interpretation of Geochemical Maps, Additional tables, Figures, Maps, and Related Publications. Geological Survey of Finland, Otamedia Oy, Espoo.

DIRIX, K., MUCHEZ, P., DEGRYSE, P., KAPTIJN, E., MUSIC, B., VASSILIEVA, E., POBLOME, J. 2013: Multi-element soil prospection aiding geophysical and archaeological survey on an archaeological site in suburban Sagalassos (SW-Turkey). Journal of Archaeological Science 40, 2961-2970.

DORE, C. D., LÓPEZ VARELA, S. L. 2010: Kaleidoscopes, Palimpsests, and Clay: Realities and Complexities in Human Activities and Soil Chemical Residue Analysis. Journal of Archaeological Science 17, 279 302.

EBERL, M., ALVAREZ, M., TERRY, R. E. 2012. Chemical signatures of Middens at a Late Classic Maya Residential Complex, Guetemala. Geoarchaeology 27, 426-440.

ENTWISTLE, J. A., ABRAHAMS, P. W., DODGSHON, R. A. 2000. The Geoarchaeological Significance and Spatial Variablility of a Range of Physical and Chemical Soil Properties from a Former Habitation Site, Isle of Skye. Journal of Archaeological Science 27, 287-303.

GABET, E. J., BOOKTER, A. 2011: Physical, chemical and hydrological properties of Ponderosa pine ash. International Journal of Wildland Fire 20, 443-452.

GRIGALAVIČIENĖ, E. Žalvario ir ankstyvasis geležies amžius Lietuvoje. Vilnius.

GUOBYTĖ, R.2002. Lietuvos paviršiaus geologijos ir geomorfologijos ypatumai bei deglaciacijos eiga. MS. Doctoral Thesis. Deposited: University of Vilnius. Vilnius.

HASLAM, R., TIBBETT, M. 2004: Sampling and analyzing metals in soils for archaeological prospection: a critique. Geoarchaeology 19, 731-751.

HJULSTROM, B., ISAKSSON, S. 2009: Identification of activity area signatures in a reconstructed Iron Age house by combining element and lipid analyses of sediments. Journal of Archaeological Science 36/2, 174-183.

HOLLIDAY, V. T. 2004: Soils and Archaeological Research. Oxford University Press, Oxford.

HOLLIDAY, V. T., GARTNER, W. G. 2007: Methods of soil P analysis in archaeology. Journal of Archaeological Science 34, 301-333.

LINDERHOLM, J. 2007: Soil chemical surveying: a path to a deeper understanding of prehistoric sites and societies in Sweden. Geoarchaeology 22/4, 417-438.

LINDERHOLM, J., LUNDBERG, E. 1994: Chemical characterization of various archaeological soil samples using main and trace elements determined by inductively coupled plasma atomic emission spectrometry. Journal of Archaeological Science 21, 303-314.

LÓPEZ VARELA, S. L., DORE, C. D. 2010: Social Spaces of Daily Life: A Reflexive Approach to the Analysis of Chemical Residues by Multivariate Spatial Analysis. Journal of Archaeological Method and Theory 17/3, 249-278.

MARWICK, B. 2005: Element concentrations and magnetic susceptibility of anthrosols: Indicators of prehistoric human occupation in the inland Pilbara, Western Australia. Journal of Archaeological Science 32, 13571368.

MEDVEDEV, A. M. 2011: Verchne Ponemane v zieleznom veke i rannem srednevekove. Minsk.

MIDDLETON, W. D. 2004: Identifying chemical activity residues on prehistoric house floors: a methodology and rationale for multi-elemental characterization of a mild acid extract of anthropogenic sediments. Archaeometry 46, 47-65.

MIDDLETON, W. D., PRICE, D. T. 1996. Identification of activity areas by multi-element characterization of sediments from modern and archaeological house floors using inductively coupled plasma-atomic emission spectroscopy. Journal of Archaeological Science 23, 673-687.

MIDDLETON, W. D., BARBA, L., PECCI, A., BURTON, J. H., ORTIZ, A., SALVINI, L., SUAREZ, R. R. 2010: The study of Archaeological Floors: Methodological Proposal for the Analysis of Anthropogenic Residues by Spot Tests, ICP-OES, and GC-MS. Journal of Archaeological Method and Theory 17/3, 183-208.

NIELSEN-MARSH, C. M., SMITH, C. I., JANS, M. M. E., NORD, A., KARS, H., COLLINS, M. J. 2007: Bone diagenesis in the European Holocene II - taphonomic and environmental considerations. Journal of Archaeological Science 34, 1523-1531.

OONK, S., SLOMP, C. P., HUISMAN, D. J., VRIEND, S. P. 2009a: Effects of site lithology on geochemical signatures of human occupation in archaeological house plans in the Netherlands. Journal of Archaeological Science 36, 1215-1228.

OONK, S., SLOMP, C. P., HUISMAN, D. J. 2009b: Geochemistry as an Aid in Archaeological Prospection and Site Interpretation: Current Issues and Research Directions. Archaeological Prospection 16, 35-51.

OTTAWAY, J. H., MATTHEWS, M. R., 1988: Trace element analysis of soil samples from a stratified archaeological site. Environmental Geochemistry and Health 10, 105-112.

PARNELL, J. J., TERRY, R. E., NELSON, Z., 2002: Soil chemical analysis applied as an interpretive tool for ancient human activities in Piedras Negras, Guatemala. Journal of Archaeological Science 29, 379-404.

REIMANN, C., SIEWERS, U., TARVAINEN, T., BITYUKOVA, L., ERIKSSON, J., GILUCIS, A., GREGORAUSKIENĖ, V., LUKASHEV, V. K., MATINIAN, N. N., PASIECZNA, A. 2003: Agricultural Soils in Northern Europe: A Geochemical atlas. Hannover.

RUSSO, M., HORAK, V. 2000: Soil Science for Archeologists. Florida Agricultural and Mechanical University and Southeast Archeological Center. National Park Service.

SALISBURY, R. B. 2016: Soilscapes un archaeology. Settlement and Social Organization in the Neolithic of the Great Hungarian Plain. Archaeolingua, Budapest.

SCHIFFER, M. 1987: Formation Processes of the Archaeological Record. University of Utah Press, Albuquerque.

STANČIKAITĖ, M., ŠINKŪNAS, P., RISBERG, J., ŠEIRIENĖ, V., BLAŽAUSKAS, N., JAROCKIS, R., KARLSSON, S., MILLER, U. 2009: Human activity and the environment during the Late Iron Age and Middle Ages at the Impiltis archaeological site. NW Lithuania. Quaternary International 203, 74-90.

ŠMIGELSKAS, R. 2013. Bèčionių piliakalnis. In: Archeologiniai tyrinejimai Lietuvoje 2012 metais. Vilnius, 131-133.

TAKAHASHI, G. 2015: Sample preparation for X-ray fluorescence analysis III. Pressed and loose powder methods. Rigaku Journal, 31/1, 26-30.

VASKS, A. 1999. Latvian archaeology: research and conclusions. In: Jensen, O. W., Karlsson, H., Vijups, A. (Eds.): Inside Latvian archaeology. Gotarc series A, Vol. 2, 3-89.

VASSILEV, S. V., BAXTER, D., ANDERSEN, L. K., VASSILEVA, C. G. 2013: An overview of the composition and application of biomass ash. Part 1. Phase-mineral and chemical composition and classification. Fuel $105,40-76$. 
WANG, L., WANG, X., ZHANG, J. 2013. Evaluating Loss-on-Ignition Method for Determinations of Soil Organic and Inorganic Carbon in Arid Soils of Northwestern China. Pedosphere 23/5, 593-599.

WANG., L., DIBDIAKOVA. J. 2014: Characterization of Ashes from Different Wood Parts of Norway Spruce Tree. Chemical engineering transactions 37. 37-42.

WELLS,. C. E., 2004. Investigating activity patterns in prehispanic plazas: weak acid extraction ICP-AES analysis of anthrosols at classic period E Coyote, Northwestern Honduras. Archaeometry 46, 67-84.
WILSON, C. A., DAVIDSON, D. A., CRESSER, M. S. 2008: Multi-element soil analysis: an assessment of its potential as an aid to archaeological interpretation. Journal of Archaeological Science 35, 412-424.

WILSON, C. A., DAVIDSON, D. A., CRESSER, M. S. 2009. An evalutation of the site specificity of soil elemental signatures for identifying and interpreting former functional areas. Journal of Archaeological Science 36, 2327-2334 
